Towards A Model of Territorial

Expansion and the Limits of Empire

by

Ronald Findlay, Columbia University

Discussion Paper \# 707 


\title{
Towards A Model of Territorial \\ Expansion and the Limits of Empire*
}

\author{
by \\ Ronald Findlay \\ Columbia University
}

*An earlier version of this paper was presented at a conference on "Conflict and Rent-Seeking" at the University of California, Irvine, in May 1994. I would like to thank the participants at that conference and at a Columbia University Political Economy Seminar in September 1994 for very helpful comments. Several friends and colleagues have also given me the benefit of their criticism. Though I cannot mention all of them I must acknowledge in particular the comments of David Bloom, Alessandra Casella, Richard Clarida, Andrew Newman, Stanislaw Wellisz and Murray Wolfson. All remaining defects are of course my own responsibility. 


\section{Towards A Model of Territorial Expansion and the Limits of Empire}

"The question of the size of political units never seems to attract among historians and sociologists the attention which it deserves. What determines why states and empires have expanded to the limits which they have historically achieved? What are the conditions under which it has been possible to maintain those frontiers? Why have the larger states normally broken up into fragments after a certain period of time? As a general problem--distinct from the specific question of why particular units have disintegrated--this is still largely unexplored territory."

Adding economists to historians and sociologists in the first sentence of this quotation from the eminent Sinologist, Mark Elvin (1973, p.17) only enhances its salience. In so far as they are considered at all in economics, the boundaries of a given economic system or "country" are generally regarded as given, along with the population living within those boundaries. Yet it is obvious that however sanctified these boundaries may have become in international law they were all at one time or another contested between rival claimants and determined ultimately by the balance of economic and military power between the contending parties. The process by which these boundaries are determined and defined clearly depends upon the interplay of economic and military forces, which have however generally been regarded as independent factors.

Elementary textbooks frequently introduce the production-possibilities frontier between "guns" and "butter" to illustrate the nature of the economic problem and the concept of opportunity cost. It is noteworthy, however, that they never, as far as I am aware, consider the question of how "guns" might be used in a predatory fashion to acquire resources from 
neighboring peoples or states and thus push out the production-possibilities frontier of the society itself. As Jack Hirshleifer (1987, p. 297) points out in his brief but penetrating survey of the little that we have on "The Economic Approach to Conflict":

"The institutions of property and law, and the peaceful process of exchange, are highly beneficial aspects of human life. But the economist's inquiries should not be limited to such "nice" behaviors and interactions. Struggle, imposing costs on others, and downright violence are crucial phenomena of the world as we know it. Nor is the opposition between the "nice" and the "not nice" by any means total. Law and property, and thus the possibilities of peaceful exchange, can only persist where individuals are ultimately willing to use violence in their defense."

While the literature on violence and coercion as "rational" economic options, subject to the usual calculus of benefits and costs is scarce, it is by no means devoid of insightful contributions, upon which I attempt to build in this paper. Kenneth Boulding (1962) in a work entitled Conflict and Defense: $A$ General Theory, has many wise and interesting things to say about the subject. I found his chapters 12 and 13 , on international conflict, particularly stimulating. Other important references are Bush and Mayer (1974), Friedman (1977), Thompson and Faith (1981), Usher (1989), Hirshleifer (1991) and Skaperdas (1992). An interesting alternative to the approach taken here, through coercion and violence as rational activities, is the "mergers and acquisitions" view of Wittman (1991). 


\section{(a) The Basic Model}

Consider, to begin with. a collective entity or "tribe" such as the Romans, Han Chinese or Ottoman Turks. The primary resource owned by the tribe is their labor, which we will assume to be initially fixed. We also suppose that there is only a single final output, that we can identify with agriculture, although a second "crafts" or "manufacturing" sector will be introduced later. Production of the final output requires land or "territory", which is not simply given but has to be acquired and held against the tribe's enemies who surround it. To fix ideas let us conceive of the labor of the tribe as concentrated at a single point on a "featureless plain" so beloved by the location theorists. We can think of this central point as its "home base". To secure and hold territory the tribe must devote some of its labor force to fighting. We can call those so engaged the "army" of the tribe, with the remainder as the "workers".

Letting $N$ denote the total size of the tribe, $A$ the army and $L$ the workers we have the manpower constraint of the tribe as

$$
L+A=N
$$

while the production function for final output, denoted $Q$, has labor and "territory", denoted $T$, as its arguments

$$
Q=Q(L, T)
$$

We assume that the production function (2) exhibits constant returns to scale and diminishing returns to either factor with the other held fixed. The territory that the tribe can 
acquire and defend against its enemies, an undifferentiated mass of "barbarians", is given by the function

$$
T=a \pi r(A)^{2}
$$

where $r$ is the radius of a circle centered on the original point, the "home base" of the tribe, and $a$ is a constant. We postulate that

$$
r^{\prime}(A)>0, \quad r^{\prime \prime}(A)<0
$$

i.e. the larger the army the greater is the radius of the tribe's "sphere of influence" but, there is a diminishing returns effect of increases in the size of the army on the radius of the circular territory that it can control and defend. Since the area of the circle, $a \pi r(A)^{2}$, is a convex function of the radius, however, the territory occupied could still increase more than proportionately to the size of the army. We shall initially assume, however, that the absolute value of the negative second derivative in (4) is sufficiently high to give us $T$ as a concave function of $A$, so that

$$
\frac{d}{d A}\left(\frac{d T}{d A}\right)<0
$$

What does the tribe want to maximize? Territory could conceivably be desired for its own sake, for the kind of pleasure that British schoolboys were supposed to get from seeing so much of the map of the world painted red in the days when the sun never set on their empire. However, let us suppose initially that the tribe is narrowly "rational" and desires territory only for its contribution to production. The economic problem of empire then is simply to maximize (2) subject to the manpower constraint (1) and the "sphere of influence" function (3). The obvious trade-off is that each man added to the army adds economically valuable land that raises final 
output but withdraws a man from the labor force that works on the land. Because of (5), the extra land added as the army is extended declines at the margin, while the marginal productivity of the falling labor force on the increased land obtained by the expanding army is rising. When the marginal productivity of a warrior is equal to that of a worker we have the optimal size of the army and associated extent of territory, which maximizes final output.

The first-order condition for the optimal size of empire is

$$
\frac{\partial Q}{\partial L}=\frac{\partial Q}{\partial T} \frac{d T}{d A}=\frac{\partial Q}{\partial T} 2 a \pi r^{\prime}(A)
$$

in which the left-hand side is the marginal productivity of a worker and the right-hand side the marginal productivity of a warrior. This condition can also be interpreted as stating that the marginal rate of substitution between land and labor in production is equal to the marginal product of a warrior in terms of territory, which is $2 a \pi r^{\prime}(A)$.

The "sphere of influence" function $r(A)$ clearly depends upon the relative military proficiency of the tribe and the barbarians. Fluctuations in the "relative military efficiency" variable, brought about say by diffusion of weapons or tactics from one side to the other, would lead to pulsations in the size of the empire in response. Thus adoption of iron for weapons by the steppe nomads, brought about by contact with China, led to a rise in their relative military efficiency and hence made the holding of the size of the Chinese empire at its original level more difficult. Technology could however flow in the other direction also. As pointed out by Creel (1970) the sedentary Chinese were dependent on the steppe nomads not only for the provision of horses for cavalry, but also for techniques of riding and training these essential military assets for 
control of the frontier. Similarly the Germanic tribes north of the Roman frontier also learnt from the imperial power, especially after many of them come to be employed as mercenaries in the Roman army.

Improvements in production technology, however, have an ambiguous effect on the size of the army and the empire. An additional acre of land is worth more, so the marginal productivity of a warrior goes up, but so does his opportunity cost, which is the marginal productivity of a worker. Thus the effect of the technical improvement on the relative marginal products of land and labor in production is what determines the impact of the innovation on the size of the army and the extent of the empire.

By what means are resources allocated between farming and fighting, and how is the final output divided between warriors and workers on the one hand, and these and the "ruling elite" of chiefs, priests and officials on the other? Here a variety of outcomes is possible. The territory could be allocated by the leader of the tribe to his relatives and other privileged individuals, who then hire labor in a free market to work on the land at the going wage-rate. The army could recruit soldiers in the same labor market, and the optimal result defined by (6) could be brought about by giving just enough tax revenue to the army to hire the optimal $A$ at the market-clearing wage $w$, equal to the marginal product of both warriors and workers.. The taxes could be raised on rents of land distributed to the privileged elite or on the labor force as a whole, preserving efficiency in allocation. Taxes only on workers would equate the after-tax civilian wage to the army wage, implying too few civilian workers and too large on army.

At the other extreme we could imagine that all the land was the property of the tribe as a whole, with the surplus of output above subsistence for all distributed in some arbitrary fashion 
to the optimally determined members of the army and civilian workers and privileged elite. Since most historic empires had great difficulty collecting taxes it could be that the optimal size of army could not be maintained, because of a shortage of revenue. Thus the size of the empire would shrink below the optimal level determined above to whatever was possible given the revenue constraint, minus luxury consumption by the elite. At the level of generality of the present paper it would be a distraction to consider particular institutional alternatives in detail, though this would be an interesting subject for further research.

\section{(b) Absorption of Subject Populations}

Up to now we have been assuming that it is only territory that the tribal army acquires. The alien population is either exterminated or expelled, "ethnic cleansing" as we have come to call it in our enlightened age. While such horrors have certainly not been unknown in the records of historic empires, reason, if not compassion, dictated that the conquered populations, and not only the land that they lived on, were valuable assets that could be enslaved, enserfed or simply taxed, at higher rates than the members of the tribe themselves. Cultural assimilation to the language and customs of the conquerors could ultimately result in such enlightened outcomes as the extension of Roman citizenship to all the subjects of the empire. Conversion to the religion of the conquerors was of course another major avenue of assimilation, as in the case of the early Arab empire and that of the Ottoman Turks.

The model can be readily modified to take account of this important feature of all historic empires. We assume that the alien population that is absorbed increases as a function of the territory that the tribe acquires. Assuming complete assimilation for simplicity we have $N$ in the 
manpower constraint ( 1 ) as a positive function of the territory $T$, which of course is itself a positive but concave function of the size of the army. The marginal benefit of adding a warrior is then not only the additional territory he brings in but the people along with it, valued at their shadow price which is the marginal productivity of labor in production. The manpower constraint (1) now becomes

$$
L+A=N[T(A)]
$$

while the first-order condition (6) is now

$$
\left\{\frac{\partial Q}{\partial L} \frac{d N}{d T}+\frac{\partial Q}{\partial T}\right\} \frac{d T}{d A}=\frac{\partial Q}{\partial L}
$$

The empire now not only has territory but an alien population absorbed within its borders as well. As noted earlier there is a very wide array of different practices known to history about the manner in which the subject population is treated relative to members of the original tribe. In the case of Sparta and the helots the Spartans themselves did not follow any occupation other than warfare and the supervision of the helots, who did all the productive work. On the other hand we have the Mamelukes of Egypt and the Janissaries of the Ottoman Turks, exclusively alien-born military elites in the service of theses realms.

\section{(c) Local and Global Optima}


As we have seen the concave function $r(A)$ and the extent of the territory associated to it by the factor of $\pi r(A)^{2}$ can interact to make territory $T$ either a concave or a convex function of the size of the army. While in the case of the basic model we assumed that it was concave throughout it is interesting to consider the possible implications of the $T(A)$ function being convex over an initial range and concave only after a certain critical size is passed. ${ }^{1}$

In Figure 1, the monotonically positive relation $L L^{\prime}$ depicts the rising opportunity cost of additional warriors in terms of their marginal productivity as workers with an increasing supply of land resulting from increases in the size of the army. The function $A A^{\prime}$ however depicts the marginal productivity of warriors $\frac{\partial Q}{\partial T} \frac{d T}{d A}$ as first rising and then falling only after the level of $\bar{A}$ is reached. The $A A^{\prime}$ function cuts $L L^{\prime}$ at three points, denoted $\alpha, \beta$ and $\gamma$ corresponding to army levels of $A_{1}, A_{2}$ and $A_{3}$. It is apparent, from the Figure 1 that $\alpha$ and $\gamma$ are stable equilibria while $\beta$ is unstable. This is because to the left of $\alpha$ and $\gamma$ the marginal product of a warrior exceeds his marginal opportunity cost while to the right it falls short of it. The opposite is the case with $\beta$. If there are no constraints on the level of the army that a unified decision-making process can determine and there is full information about the relevant functions the outcome will of course be the global optimum at $A_{3}$ and the corresponding $T_{3}\left(A_{3}\right)$. If these conditions are not fulfilled, however, the situation could be analogous to the familiar "low level equilibrium trap" of development economics. There will be no incentive to expand beyond $A_{l}$ if the decision-makers are "myopic" and the equilibrium will therefore be at the locally stable point $\alpha$ in this case, with army level $A_{l}$ and associated territory $T_{l}\left(A_{\nu}\right)$. On the other hand, it might be the case that there is full information about the shapes of $A A^{\prime}$ and $L L^{\prime}$ but there could be a constraint on the possible size of the army at some point between $A_{1}$ and $A_{2}$, again leading to point $\alpha$ as the "normal" solution. 
Suppose that the original historical equilibrium is at $\alpha$. There will be no incentive to expand further if only small incremental changes take place in the size of the army. Suppose however, that under some very special circumstances a unique, charismatic leader arises who can organize an expansion in the size of the army to $A_{2}$ or beyond. Once this initial feat is performed success will be cumulative, since the marginal productivity of additional warriors will now exceed their marginal cost. Expansion can take place all the way to $A_{3}$, with the territory of the empire at the globally optimal level of $T_{3}\left(A_{3}\right)$.

Historical examples of such sudden explosive conquests are rare but not unknown. There are at least three of great interest and significance. The first is the establishment of the original Arab empire after the tribes of the Arabian peninsula had been united by the new religion of Islam preached by the Prophet. Ending their intensive feuding and banding together, and exercising spectacular mobility across the deserts, they conquered most of the land from Spain to India in a generation. Even more spectacular, though less long lived, was the unification of the Mongols under Genghis Khan. Their historic equilibrium was a "tribal confederacy", a loosely knit association that subsisted on a parasitic relation with their more sedentary and wealthier neighbors. Genghis Khan, by a mixture of ruthlessness and daring, welded the various tribes unto a centralized steppe kingdom before launching his whirlwind conquests of the civilized world from China to the borders of Poland. A final example is that of the Zulu chief Shaka early in the 19th century in Southern Africa, with his combination of military innovations and terror against rival chieftains. The fact that all three great conquests were difficult to sustain shows how hard it was to establish them initially, dependent as they were on the emergence of truly extraordinary personalities ${ }^{2}$. 


\section{(d) A Manufacturing Sector}

Up to now we have identified production with land and agriculture. How will the introduction of a manufacturing sector alter the determinants of the optimal size of territory and population? We will suppose that manufacturing does not require any land at all, only labor and a specific input capital. For simplicity, we will take this stock of specific manufacturing capital as fixed. The model will now have an additional production function for manufacturing

$$
M=M\left(L_{11}, \bar{K}\right)
$$

where $M$ is output of manufactures, $\bar{K}$ is the specific input of capital and $L_{M}$ is labor employed in manufacturing. The man-power constraint (7) is now

$$
L_{A}+L_{A}+A=N[T(A)]
$$

where $L_{4}$ denotes labor in agriculture.

We suppose that the relative valuation of the two goods $Q$ and $M$, with $Q$ as the numeraire, is a constant $p$. This constant could be thought of either as a relative price on a world market in which our economic system is imbedded, or a constant marginal rate of substitution in a linear utility function. National income will be

$$
Y=Q+p M
$$

The augmented model thus corresponds closely to the familiar Ricardo-Viner model of international trade theory, expounded in Jones (1971) and Samuelson (1971). The significant 
difference of course is that the supplies of the specific input land $T$, and the overall labor force, $N$, are both endogenous instead of fixed. as a result of our hypotheses in (3), (4), (5) and (7).

The objective of the empire is now to maximize (11) subject to the technology and the resource constraints. The first-order condition now becomes

$$
p \frac{\partial M}{\partial L_{M}}=\frac{\partial Q}{\partial L_{A}}=\left\{\frac{\partial Q}{\partial L_{A}} \frac{d N}{d T}+\frac{\partial Q}{\partial T}\right\} \frac{d T}{d A}
$$

which is the same as (8) except for the fact that the marginal productivity of labor must now be equal in three uses--the army, agriculture and manufacturing, instead of just two as before.

It is apparent that the higher is the relative price $p$, holding $N, A$ and $T$ initially constant, the larger will be $L_{M}$ and $M$ and the smaller will be $L_{A}$ and $Q$, i.e. production and labor allocation will shift in favor of $M$ and against $Q$. The marginal product of labor in agriculture will rise and the marginal product of land will fall. What will be the effect on the incentive to adjust the size of the army as a result of the rise in the relative price of manufactures?

If $\frac{d N}{d T}$ is small or negligible the effect will be to reduce the size of the army, since $\frac{\partial Q}{\partial T}$, the value of each additional acre won by the army, is now smaller. It pays instead to deploy some of the former warriors in manufacturing, and thus to sacrifice some territory. If $\frac{d N}{d T}$ is large, however, it pays to expand the army not to get more territory for its own sake, since land is now less valuable as an input, but to absorb more labor from subject populations into the work force of the empire.

It is interesting to note in this connection that in the fierce wars waged by the Burmese kings against Thailand from the 16 th to the 18 th centuries the objective was not to take and hold 
territory but to bring back large numbers of the Thai population, particularly skilled craftsmen. Slave-raiding for domestic use was also widespread in Africa and of course in the ancient world of Greece and Rome, especially the latter.

Very similar results will follow from an increase in the supply of capital. Combining these results we can say that the more important the manufacturing sector is in the economic system the less incentive will the empire have to expand its army and its territorial extent. An exception to this would be when labor is scarce within the existing borders of the empire but plentiful outside it, and there is furthermore a strong comparative advantage of military force relative to the "barbarians" beyond the borders.

A more important exception, however, would be the inclusion of manufactured output as an input, along with the army, in the conquest or "sphere of influence" function, so that instead of simply $r(A)$ in (3) and (4) we have instead

$$
T=\operatorname{arn}\left(A, M_{A}\right)^{2}
$$

where $M_{A}$ is manufacturing input, such as arms, that is complementary to the army $A$. The partial derivative of $\mathrm{r}$ with respect to $M_{A}$ would be positive and the second derivative negative, analogous to the conditions regarding the relationship between $r$ and $A$ in (4). The cross partials of $A$ and $M_{A}$ are positive.

Introducing a "military - industrial complex" in this way clearly opens up many interesting and relevant considerations. Technical progress or capital accumulation in manufacturing now not only raises the opportunity cost of a soldier but potentially increases his marginal product as well. Thus, on balance, it would be possible to have manufacturing progress lead to an extension of conquest and aggression as a result of enhanced military effectiveness, 
particularly if the improvement is confined, at least initially, to the empire itself. Such temporary but nevertheless long sustained monopolies of bronze or iron weapons, chariots or firearms have been major factors in the annals of conquest and the rise of empires.

\section{(e) Reaction Functions and the Balance of Power}

The model has so far dealt with the opponents beyond the borders of the empire as an undifferentiated mass, without any conscious strategy of their own in response to that of the empire. In many historical cases, however, we have the clash of two or even more empires, each with a unified strategy relative to the opponents. Even with each examples as the Germanic tribes beyond the Roman frontiers, or the steppe nomads in the case of China, the "barbarians" frequently banded together to coordinate their offensive and defensive measures.

To analyze this problem let us consider the following highly stylized extension of our basic model. Suppose that the entire "space" with which the model is concerned is now finite, a circle with unit radius centered on the "home base" of our original tribe. The tribe strives to capture and hold a circular area centered on this point, with the fraction of the unit radius under its control determined by the relative sizes of its own "army" and that of its opponent. For any given disposition of the two forces the original tribe holds the inner of two concentric circles, while the opponent retains the complementary area of the outer circle.

Let us call the area held by the tribe the "Heartland" and that held by its opponents the "Rimland," in the evocative terminology of the great geopolitical theorist Sir Halford Mackinder, as depicted in Figure 2. Denoting the fraction of the unit radius held by the Heartland as $\lambda$, and $A_{H}$ and $A_{R}$ as the sizes of the two opposing forces, we postulate that 


$$
\begin{aligned}
& \lambda=\lambda\left(A_{H}, A_{R}\right) \\
& \frac{\partial \lambda}{\partial A_{H}}>0, \quad \frac{\partial \lambda}{\partial A_{R}}<0
\end{aligned}
$$

with negative second derivatives in each case.

Thus given $A_{R}$ we see that $\lambda\left(\mathrm{A}_{\mathrm{H}}\right)$ behaves exactly like our earlier function $r(A)$ in the basic model. An increase in $A_{R}$ will reduce $\lambda\left(\mathrm{A}_{H}\right)$ for any given value of $A_{H}$. Similar relations will hold for $A_{R}$, given $A_{H}$. With technology and resource endowments specified for each side we can determine the optimum $A_{H}$ for given $A_{R}$ and vice versa. This enables us to derive the "reaction functions" $H H^{\prime}$ and $R R^{\prime}$ in Figure 3. These functions are both negatively sloped, for reasons explained above. If $H H^{\prime}$ is steeper than $R R^{\prime}$, as we shall assume, the intersection of the two curves yields a stable equilibrium or "balance of power" with $A_{H}{ }^{*}$ and $A_{\mathrm{R}}{ }^{*}$ as the optimal force sizes of the two opponents and $T_{\mathrm{H}}{ }^{*}$ and $T_{R}{ }^{*}$ as the corresponding areas of the territories that they control.

What determines the fraction of the radius and hence the relative size of the territory that each side controls in this balance of power? It is clearly not just the relative military efficiency but the entire structure of the two economic systems and "ways of life." One obvious application of the model is to think of the Heartland as China, the "Central Kingdom" as it has been known to its inhabitants for millennia, and the Rimland as the domain of the pastoral nomads. The ratio of territory could be very much in favor of the latter, even though the compact central core might be much wealthier and more sophisticated, with a flourishing industry that makes land, and therefore an army, not so essential except for strictly defensive purposes. Chinese culture has traditionally found military activities distasteful, reflecting this fact. For the nomads on the other 
hand, with mobility a way of life that makes them take readily to war, a wide swathe of territory may be natural to acquire and hold.

An alternative interpretation of the model, however, would be to think of the Rimland as the more "developed" and "sophisticated" region, say because the outer land circle is surrounded by water, making transport around the rim and contact with the foreign lands across the sea much easier and therefore leading to an increase in wealth. Here it is the Heartland that could be the more pastoral and agricultural of the two regions, giving an incentive for a large army and pushing the Rimland back to a thin corridor around the boundary. It is natural to think here of Europe, with land-based kingdoms such as Prussia and Austria-Hungary in the central core and maritime Rimland nations like Portugal, Holland, England and Italy drawing their wealth from industry and overseas trade rather than land and agriculture.

\section{(f) Comments on the Literature}

While economic factors are explicitly alluded to only incidentally in his stimulating book, on A History of Warfare, the military historian John Keegan (1993) gives considerable attention to a concept developed by the sociologist Stanislaw Andreski (1968) called the Military Participation Ratio or MPR, the fraction of a population engaged in military activities. It is interesting to note that our model, instead of simply taking this MPR as given by some innate "propensity for agression", derives it from more basic structural parameters of resources and technology, though preferences could no doubt be made to play an additional role as well. Thus, the fact that many of the great empires were established by nomadic peoples can be accounted for in terms of our model as reflection of what North (1981) calls a "comparative advantage in 
violence," arising from a low opportunity cost of peaceful activities because of paucity of resources, combined with the externalities for military effectiveness generated by riding, hunting and other such practices that are a natural part of nomadic life. Manufacturing and other peaceful arts, as we have seen tend to raise the opportunity cost of maintaining armies and hence lower the MPR, though they can also enhance military efficiency through improving the technology of warfare.

Our model does also allow, however, for such cultural or social factors stressed by Andreski and Keegan as cohesion or solidarity of the conquering tribe or nation, what the great Arab historian Ibn Khaldun called assabiya. This factor is particularly important in the case of multiple equilibria analyzed earlier. Whether this factor is operative or not could determine whether or not the "high" equilibrium rather then the "low" one is determined. The more normal low state could be occasionally punctuated by great unifications and conquests brought about by charismatic leaders. After some time, however, as Ibn Khaldun points out, the bonds of assabiya tend to dissolve and the empire fragments or the dynasty lose the "mandate of heaven" as the Chinese saw it. ${ }^{3}$

Our analysis of reaction functions and the resulting balance of power is akin to the well-known mathematical model of "arms races" associated with the names of Lanchester and Richardson. The difference, however, is that we link the military sectors to the economic systems through the opportunity costs of allocating resource for war. Our model thus links the "arms race" itself into the wider context of the economy and society as a whole.

In an extensive recent comparative study of theories of empire, Doyle (1986) offers threefold classification into "metrocentric", "pericentric" and "systemic", depending upon 
whether the primary stress is laid on tendencies emanating fromt the center or metropolios in the first case, the dependent periphery in the second or the relationship between both in some wider contextual space in the third. An example of the first would be the Hobson-Lenin theory of imperialism as the attempt by developed capitalist countries to off-set a declining rate of profit at home investment in colonies. The approach of our original model of expansion by centralized entity against the resistance of "barbarians" would also fit this category, while our later analysis of competing empires through reaction functions establishing a balance of power would be an example of a "systemic" theory.

The sociologist, Michael Mann (1986) in a very amitious and interesting work, subtitled "A History of Power from the Beginning to $\mathrm{AD} 1760$," makes a distinction between "empires of domination" which exact tribute and exercise indirect control, and "territorial" empires, which conquer and administer directly. While our model is obviously entirely consistent with the second, it can also apply to the first, since the exaction of tribute and the exercise of control also require the allocation of resources to predatory rather that directly productive activities.

Both Doyle and Mann, not surprisingly, devote considerable space to the Roman Empire and its characterization. On this subject our model is entirely consistent with the view of the most eminent recent authority, William Harris (1979). Contrary to many earlier ancient historians, Harris considered the root of th Roman expansion to be the desire to accumulate land, slaves and plunder, with the greatest political and economic rewards going to those members of the Roman upper classes most successful in waging war. ${ }^{4}$ The emphasis on a rational, even though implicit, calculus of costs and benefits in extending the limits of the empire is also present in a subtle and penetrating study of the Frontiers of the Roman Empire by Whittaker 
(1994), who points out (p. 86) that "Roman emperors had some awareness, however crude, of what we would call the marginal costs of imperilism."

In a central chapter on "Why Did the Frontiers Stop Where They Did?" Whittaker rejects the idea of "natural frontiers," such as mountain ranges and rivers like the Rhine, Danube and Euphrates. Despite the authority of Tacitus and numerous subsequent authorities down to the present day, he argues that they were not impenetrable barriers or clear demarcation lines between Roman and barbarian. Rather, he adopts the view of the great student of the interaction between China and the steppe nomads of Inner Asia, Owen Lattimore (1940). Lattimore says (p. 240) "a major imperial boundary...is not merely a line dividing geographical regions and human societies. It also represents the optimal limit of growth of one particular society." He defines the optimum limit as the point at which "centripetal gain, accordingly, was converted into centrifugal loss" (p. 242), which I find to be an elegant verbal equivalent to my more cumbersome mathematical first-order conditions.

What Paul Kennedy (1987) in his influential book calls "imperial overstretch," the tendency of empires to press beyond these rational limits, can also be illustrated in our model as a desire to hold territory as a point of honor or dynastic piety, rather than rationally cutting back consistently with resource availabilities. Thus the many examples such as the Habsburgs blindly persisting in wasting the riches of their overseas possessions in trying to hold Flanders and their other European partimonies.

It would be easy to apply the model to various other historical examples and episodes but I hope to have convinced the reader already about the relevance of this analysis to the fascinating questions posed in the opening quotation from Mark Elvin. Before closing, however, I would 
like to point to the strong formal resemblence between this model and those of the division of labor between "soldiers" and "workers" among the "social insects" such as ants and wasps, studied by means of very sophisticated optimizing techniques in the classic work of Oster and Wilson (1978). Here we have another striking example of the convergence of biological and economic theory. 


\section{ENDNOTES}

1) See Wolfson (1994) for an interesting extension of my original analysis along these lines.

2) On the rise of Islam and Arab conquests see Crone (1987), chapter 10; on Genghis Khan and the Mongols see Ratchenevsky (1991) and Barfield (1989); on Shaka and the Zulus see Morris (1969) and Gluckman (1940).

3) On Ibn Khaldun see the selections from his major work translated and arranged, with a valuable introduction, by Charles Issawi (1950).

4) See also Rich and Shipley, eds. (1993) for extended discussion of the Harris thesis. 


\section{References}

Andreski, S. Military Organization and Society, University of California Press, 1968.

Barfield, T. J. The Perilous Frontier, Blackwell, 1989.

Boulding, K.E. Conflict and Defense: A General Theory, Harper, 1963.

Bush, W. C. and L.S. Mayer. "Some Implications of Anarchy for the Distribution of Property" Journal of Economic Theory, 8, p. 401-412, 1974.

Creel. H. G. "The Role of the Horse in Chinese History" in What is Taoism? and Other Studies in Chinese History, University of Chicago Press, 1970.

Crone, P. Meccan Trade and the Rise of Islam, Princeton University Press, 1987.

Doyle, M.W. Empires, Cornell University Press, 1986.

Elvin, M. The Pattern of the Chinese Past, Stanford University Press, 1973.

Friedman, D. "A Theory of the Size and Shape of Nations" Journal of Political Economy, February, 1977.

Gluckman, M. "The Kingdom of the Zulu of South Africa" in M. Fortes and E. E. Evans-Pritchard eds. African Political Systems, Oxford University Press, 1979.

Harris, W.V. War and Imperialism in Republican Rome 327 -70 BC. Oxfod University Press, 1979.

Hirshleifer, J. Economic Behavior in Adversity, University of Chicago Press, 1987.

-....- "The Technology of Conflict as an Economic Activity," American Economic Review, May 1991.

Issawi, C. An Arab Philosophy of History, John Murray, London, 1950.

Jones, R. W. "A Three-Factor Model in Theory, Trade and History" in J. Bhagwati et. al. (eds.), Trade. Balance of Payments and Growth, North-Holland, 1971.

Keegan, J. A History of Warfare, Knopf, New York, 1993.

Kennedy, P. The Rise and Fall of the Great Powers, Random House, New York, 1987.

Lattimore, O. Inner Asian Frontiers of China, Beacon Press, New York, 1960 [First edition published by American Geographical Society, New York, 1940]. 
Mann. M. The Sources of Social Power, vol. 1, Cambridge University Press, 1986.

Morris, D.R. The Washing of the Spears. Simon and Schuster, New York, 1969.

Oster, G.F. and E.O. Wilson. Caste and Ecology in the Social Insects, Princeton University Press, 1978.

Ratchnevsky, P. Ghengis Khan, Blackwell, 1991.

Rich, J. and G. Shipley (eds.) War and Society in the Roman World, Routledge, London, 1993.

Samuelson, P.A. "Ohlin Was Right," Swedish Journal of Economics, no. 73, 1971.

Skaperdas. S. "Cooperation, Conflict and Power in the Absence of Property Rights," American Econmic Review, September, 1992.

Thompson, E. and R. Faith. "A Pure Theory of Strategic Behavior and Social Institutions," American Economic Review, June 1981.

Usher, D., "The Dynastic Cycle and the Stationary State," American Economic Review, December, 1989.

Whittaker, C.R. The Frontiers of the Roman Empire, Johns Hopkins University Press, Baltimore, 1994.

Wittman, D. "Nations and States, Mergers and Acquisitions, Dissolutions and Divorce," American Economic Review, May ,1991.

Wolfson, M. "A Note on Growth, Politics and War" mimeo, University of California, Irvine, 1994. 


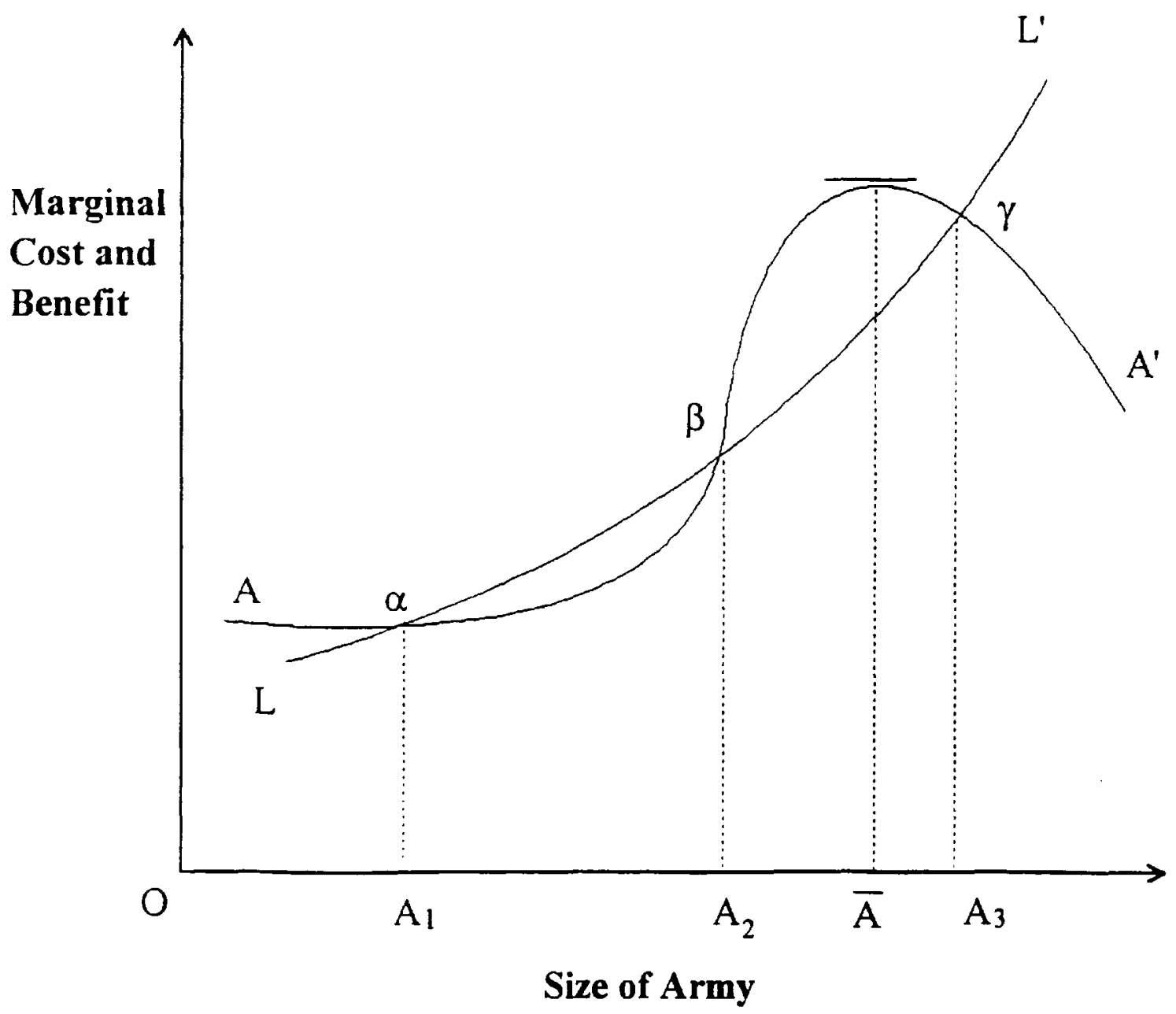

Figure 1 


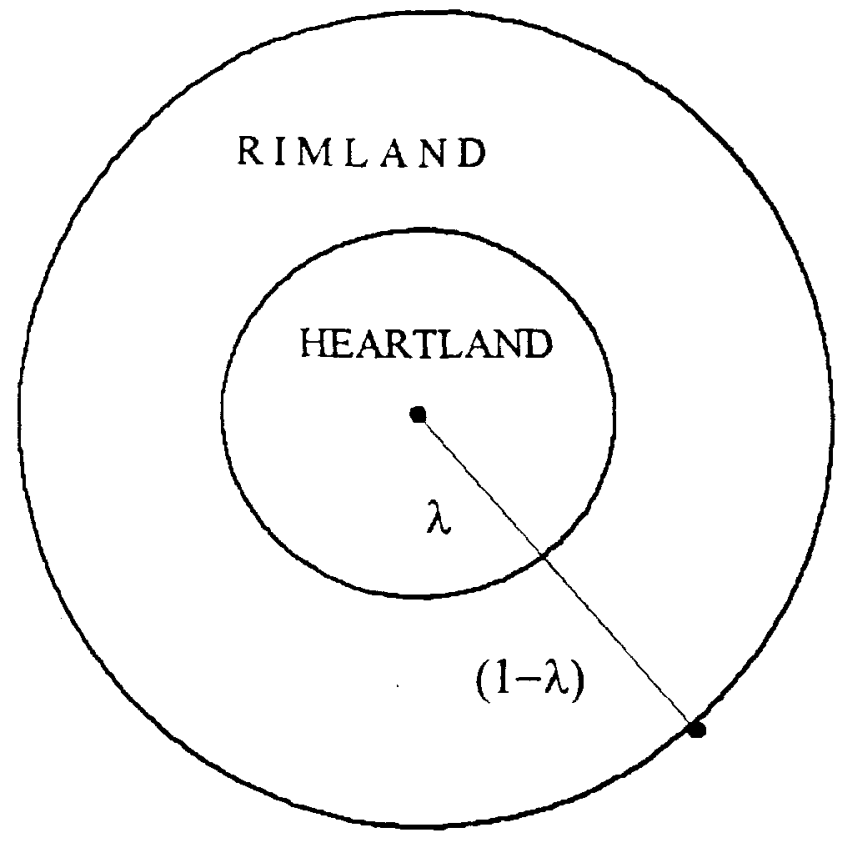

Figure 2 


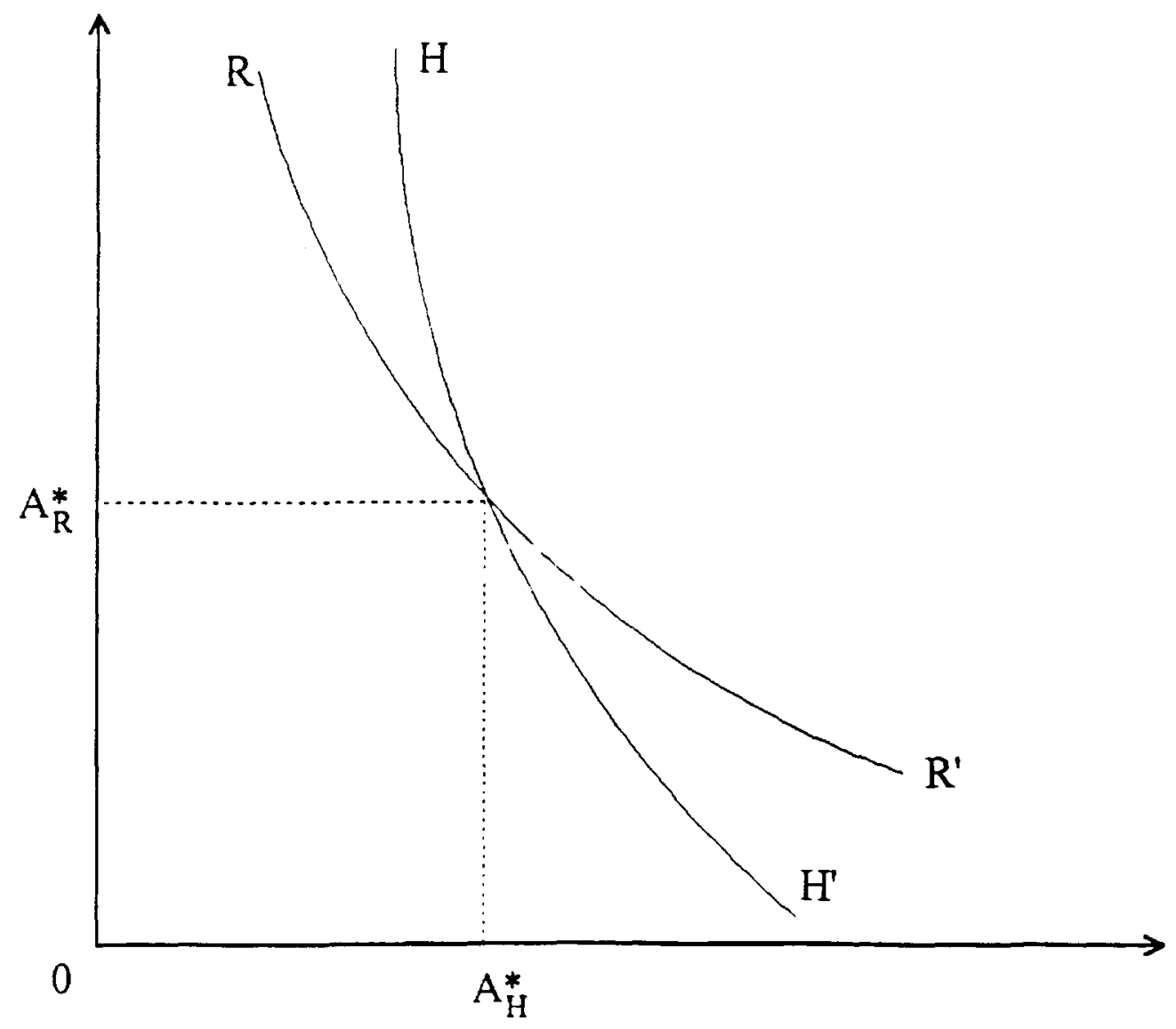

Figure 3 


\section{3-94 Discussion Paper Series \\ Department of Economics \\ Columbia University \\ 420 W. 118 St., Room 1022 \\ New York, N.Y., 10027 \\ Librarian: Angie Ng}

The following papers are published in the 1993-94 Columbia University Discussion Paper series which runs from November 1 to October 31. Domestic orders for discussion papers are available for purchase at $\$ 5.00$ (U.S.) each and $\$ 140.00$ (U.S.) for the series. Foreign orders cost $\$ 8.00$ (U.S.) for individual paper and $\$ 185.00$ for the series. To order discussion papers, please send your check or money order payable to Department of Economics, Columbia University to the above address. Please be sure to include the series number for the paper when you place an order.

671. Investment in U.S. Education and Training

Jacob Mincer ( Nov. 1993)

672. Freer Trade and the Wages of the Unskilled: Is Marx Striking Again?

Jagdish Bhagwati and Vivek Dehejia

673. Employer Size and Labor Turnover

Todd Idson

674. Less Crime May Be Worse

Brendan O'Flaherty

675. Team Production Effects on Earnings

Todd Idson

676. Language, Employment, and Earnings in the United States:

Spanish-English Differentials from 1970 to 1990

David Bloom and Gilles Grenier

677. The Impact of Performance Incentives on Providing Job Training to the Poor: The Job Training to the Poor: The Job Training Partnership Act (JTPA)

Michael Cragg

678. The Demands to Reduce Domestic Diversity among Trading Nations Jagdish Bhagwati

679. Mass Layoffs and Unemployment Andrew Caplin and John Leahy 
680. The Economics of Adjustment

Andrew Caplin and John Leahy

681. Miracle on Sixth Avenue: Information Externalities and Search Andrew Caplin and John Leahy

682. Arbitrage, Gains from Trade and Scoial Diversity: A Unified Perspective on Resource Allocation

Graciela Chichilnisky

683. Who should abate carbon emissions?

Graciela Chichilnisky, Geoffrey Heal

684. Believing in Multiple Equilibria

Graciela Chichilnisky

685. Limited Arbitrage, Gains from Trade and Arrow's Theorem Graciela Chichilnisky

686. International Emission Permits: Equity and Efficiency Graciela Chichilnisky, Geoffrey Heal and David Starrett

687. Do Vehicle Emissions Testing Program Improve Air Quality? Matthew Kahn

688. Sources of Real Exchange Rate Fluctuations: How Important Are Nominal Shocks? Richard Clarida and Jordi Gali

689. Modeling Soviet Agriculture for Assessing Command Economy Policies Padma Desai and Balbir Sihag

690. The Changing Labor Market Position of Canadian Immigrants David Bloom, Gilles Grenier and Morley Gunderson

691. Herd Behavior, the " Penguin Effect ", and the Suppression of Informational Diffusion: An Analysis of Informational Externalities and Payoff Interdependency Jay Pil Choi

692. Shock Therapy and Russia: Was It Tried? Why Did It Fail? What Did It Do? What Now?

Padma Desai 
693. Changes in the Structure of Family Income Inequality in the United States and Other Industrial Nations during the 1980s

McKinley L. Blackburn and David E. Bloom

694. Necessarily Welfare-enhancing Customs Unions with Industrialization Constraints: a Proof of the Cooper-Massell-Johnson-Bhagwati Conjecture Pravin Krishna and Jagdish Bhagwati

695. The Effect of Household Characteristics on Household-Specific Inflation Rates: An Application to Trends in Child Poverty and Educational Real Wage Differentials

Todd Idson and Cynthia Miller

696. Threats to the World Trading System: Income Distribution and the Selfish Hegemon Jagdish Bhagwati

697. Intraindustry Trade: Issues and Theory Jagdish Bhagwati and Donald R. Davis

698. A Characterization of Cointegration Phoebus Dhrymes

699. The Production of Human Capital and the Lifecycle of Earnings: Variation on a Theme Jacob Mincer

700. The Philosophy of Locational Competition Ronald Findlay

701. Size, Sunk Costs, and Judge Bowker's Objection to Free Trade John McLaren

702. Identification and Kullback Information in the GLSEM Phoebus Dhrymes

703. Patent Litigation as an Information Transmission Mechanism Jay Pil Choi

704. On the Meaning of Certain Cointegration Tests Phoebus J. Dhrymes

705. Housing Partnerships: A New System of Housing Finance Andrew Caplin, Charles Freeman, Joseph Tracy 
706. The Optimal Income Tax Schedule ( Revised Version ) Kelvin Lancaster

707. Towards A Model of Territorial Expansion and the Limits of Empire

Ronald Findlay 